\title{
The microbial community on aggregates in the Elbe Estuary, Germany
}

\author{
Heike Zimmermann* \\ Institut für Hydrobiologie und Fischereiwissenschaft, Hydrobiologische Abteilung, Universität Hamburg, Zeiseweg 9. \\ D-22765 Hamburg, Germany
}

\begin{abstract}
In 1995, an extensive investigation was carried out in the Elbe Estuary in Germany between Cuxhaven and Geesthacht. Special attention was paid to microorganisms, including bacteria, amoebae, ciliates and flagellates, which were dispersed in the water column and associated firmly or loosely with different types of aggregates. The abundance, size and colonization by microorganisms of the aggregates varied in the limnetic, brackish and marine environments. There were differences in the locations of occurrence and abundance at each site, attributable to differences in the physical and chemical conditions. The composition of the aggregates mainly reflected the structure of the plankton community and also the benthic environment. In the upper estuary, aggregates were composed mainly of organic material, and most of the associated material consisted of remnants of the plankton. About $85 \%$ of the particles were colonized by bacteria, and $25 \%$ by protozoans. Abundances of dispersed bacteria varied between $0.6 \times 10^{9}$ and $25.5 \times 10^{9}$ bacteria $\mathrm{l}^{-1}$, and dispersed protozoan abundance ranged between $241 \times 10^{3}$ and $8778 \times 10^{3} \mathrm{l}^{-1}$ Attached bacteria reached concentrations between $0.3 \times$ $10^{6}$ and $22.5 \times 10^{6}$ bacteria $\mathrm{I}^{-1}$, while attached protozoans numbered from 98 to $22500 \mathrm{l}^{-1}$ Attached bacterial density accounted for about $75 \%$ of total bacterial density during the year. About $90 \%$ of the total bacterioplankton in the upper estuary were tightly attached to aggregates; only $40 \%$ were similarly attached in the lower estuary. During the whole year, aggregates in the lower parts of the estuary were dominated by mineral particles, and they were not as densely colonized as in the upper part. Dispersed and attached organisms in the Elbe Estuary showed an annual seasonal succession.
\end{abstract}

KEY WORDS: Elbe - Estuary Aggregate C Colonization A Attached organisms P Particles - Protozoa Bacteria

\section{INTRODUCTION}

Estuaries are regarded as complex ecosystems, influenced by physical and chemical factors both temporally and spatially. They are among the most productive ecosystems in the world (Mc Cluskey 1989), and the dynamic boundary between fresh and salt water is thought to be an important interface for biological reactions.

The last decade has seen a great deal of attention focussed on bacterial and protozoan plankton (Pomeroy 1974, Williams 1981, Azam et al. 1983). Tintinnid ciliates have attracted a relatively large amount of attention in estuaries (Hedin 1975, Har-

•E-mail: hz@rrz.uni-hamburg.de greaves 1981, Burkill 1982, Capriulo \& Carpenter 1983, Henrot 1983, Sanders 1987, Sime-Ngando et al. 1995). They can be important grazers during the annual cycle (Burkill 1982, Capriulo \& Ninivaggi 1982). However, they are usually outnumbered by nanoflagellates (flagellates $\leq 20 \mu \mathrm{m} ; \mathrm{NF}$ ) and large flagellates (flagellates $\geq 20 \mu \mathrm{m} ;$ LF). Because of methodological difficulties, there have been only a small number of detailed studies devoted to the flagellates of estuaries and other brackish water bodies (Smetacek 1981, Fenchel 1982, Anderson \& Sørensen 1986, Hansen 1991).

Large numbers of aggregates, which are fragile, amorphous microscopic particles of different forms and sizes (Grossart \& Simon 1993), are a conspicuous feature of the estuarine environment (Eisma 1992). Minerals, detritus and organisms, including bacteria, 


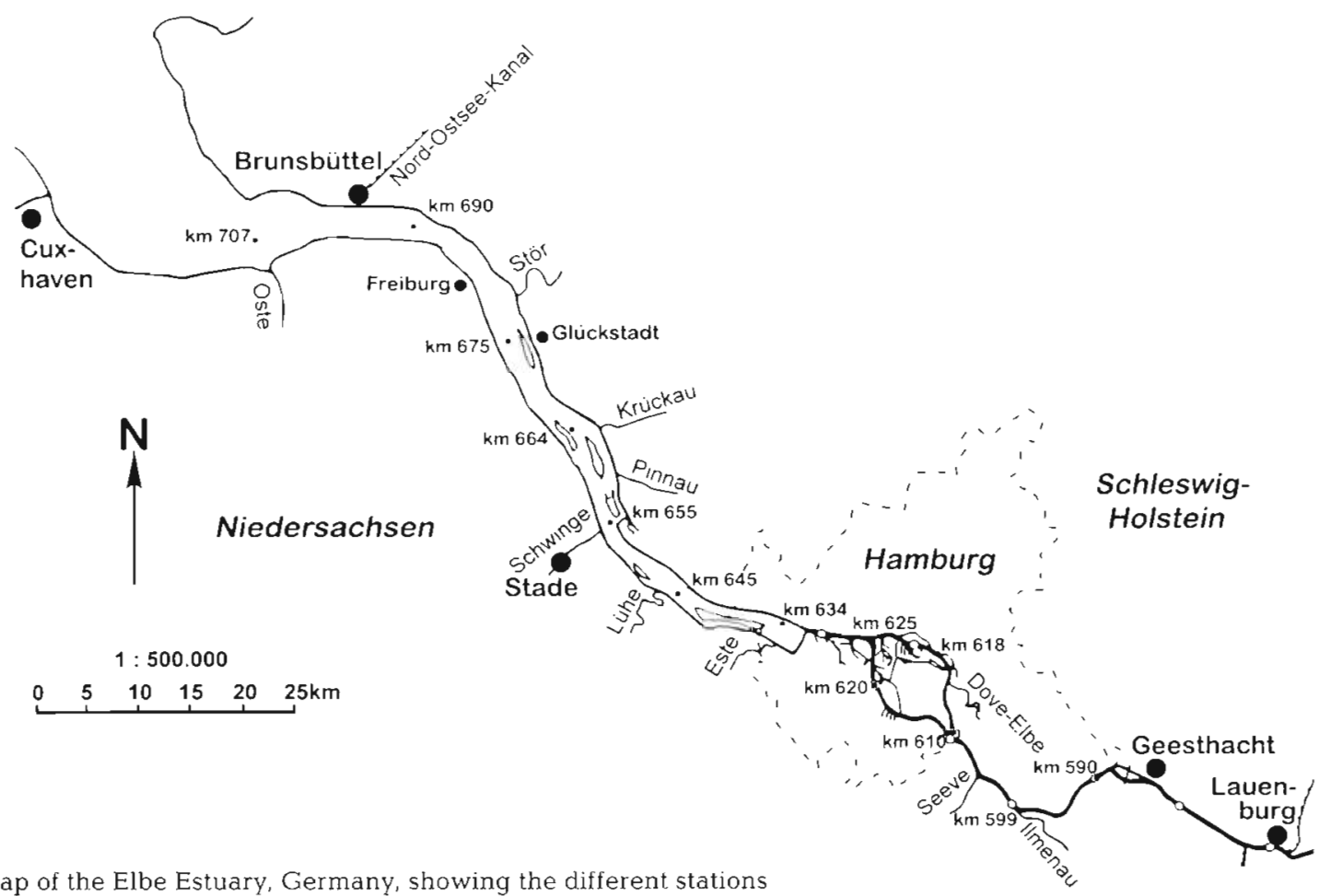

Fig. 1. Map of the Elbe Estuary, Germany, showing the different stations

protozoans, and metazoans, are components of the aggregates in estuaries (Goulder 1976, 1977, Greiser 1988, Eisma 1992, Laybourn-Parry et al. 1992, Rogerson \& Laybourn-Parry 1992a, b, Kies 1995, Zimmermann \& Kausch 1996, Zimmermann et al. in press) Nevertheless, information on the microbial organisms in the water column and on aggregates in estuarine environments is scarce (Laybourn-Parry et al. 1992, Rogerson \& Laybourn-Parry 1992a, b, Crump \& Baross 1996). Because of methodological difficulties, only 1 investigation has been carried out on the colonization of single aggregates (Zimmermann \& Kausch 1996) in an estuary.

In the Elbe Estuary, a few reports about dispersed and associated organisms are available: Böttcher et al. (1995), Fast (1993), Holst (1996), Humann (1996), Wolfstein (1996), Wolfstein \& Kies (1995), Zimmermann (1975), Zimmermann \& Kausch (1996) and Zimmermann et al. (in press). Most of the aggregated materials are in the turbid zone where the freshwater in the river mixes with seawater (Ǩies î́9̆5). By provicing a substrate for organisms, the aggregates may influence heterotrophic turnover of organic material. Their abundance may be a sign that there is a more complex food web in pelagic waters.

Caron et al. (1982) thought that aggregates are important loci of microbial activity in the water column, similar to the much larger oceanic 'marine snow' aggregates. However, the abundance and size of aggregates show considerable seasonal (Kies 1995,
Zimmermann \& Kausch 1996) and spatial variation (Kies 1995). Giving special consideration to these 2 kinds of variation, this study was conducted to elucidate the microbial colonization of aggregates in the Elbe Estuary.

\section{MATERIALS AND METHODS}

Sampling. For an entire year, from January to December 1995, water samples were collected monthly from a boat moving with the tide up the estuary. They were taken each month, during a period of 2 or $3 \mathrm{~d}$, from 8 stations in the Elbe Estuary from Geesthacht to Cuxhaven (Fig. 1) during low tide.

Samples were taken at a depth of $1 \mathrm{~m}$ below the surface using a horizontal tube constructed by Hydro Bios in Kiel, Germany. This device samples the aggregates in flowing water without causing turbulence or destruction of the aggregates.

Planikion. Sampies were treated as ciescribed by Zimmermann \& Kausch (1996) for enumeration of planktonic bacteria, amoebae, ciliates and flagellates.

Aggregates. Aggregates were selected from the horizontal sampling tube with a Pasteur pipette and were counted under a dissecting microscope in 5 bottles with openings $5 \mathrm{~cm}$ in diameter. They had been carefully filled with $10 \mathrm{ml}$ of water. Several aggregates were always examined under a microscope at $10 x$ and classified according to morphology and composition. 
The size of the particles was measured directly using an ocular micrometer. The mean area of at least 20 particles per sample was calculated from the number of particles and the longest dimensions multiplied by the mean width of each particle.

The aggregates were kept no longer than $3 \mathrm{~h}$ in a cooling box before being examined on the ship or in the lab. Selected samples were stained with Alcian Blue, a specific stain for acidic mucopolysaccharides (Decho 1990). Amoebae, ciliates and flagellates were counted on each aggregate using the live counting technique (Zimmermann \& Kausch 1996). Bacteria were dislodged by ultrasonic vibration, stained and counted on filters (Zimmermann \& Kausch 1996).

Additional parameters. Suspended particulate matter (SPM) dry weight was determined after filtering of water through preweighed Whatman GF/C filters and drying for $24 \mathrm{~h}$ at $60^{\circ} \mathrm{C}$ (Marcus Hoberg, University of Hamburg, pers. comm.).

Temperature, conductivity and oxygen concentrations were determined at each station with a portable measurement probe (WTW OXI-96, WTW LF-96).

Chlorophyll a determinations were carried out according to the method of Nusch (1980) (see also Zimmermann \& Kausch 1996).

Water discharge rates were measured at the water depth gauge at Neu Darchau, river km 536.4, in Germany (Thomas Gaumert, ARGE Elbe in Hamburg, pers. comm.).

Evaluation of biotic and abiotic parameters. Spearman rank correlation coefficients (r) were computed among the following parameters using STATeasy: dispersed bacteria, bacteria attached to particles, number of aggregates, size of aggregates, discharge, temperature, conductivity, chlorophyll $a$, ciliates and flagellates.

\section{RESULTS}

During 1995, the Elbe Estuary received a mean monthly river discharge of $915 \mathrm{~m}^{3} \mathrm{~s}^{-1}$. Mean monthly water discharge rates varied between 337 and $1774 \mathrm{~m}^{3}$ $\mathrm{s}^{-1}$, and maximum values were determined during winter and spring with the highest value in February: $2165 \mathrm{~m}^{3} \mathrm{~s}^{-1}$ (Thomas Gaumert pers. comm.). The salinity ranged from 0.5 to $35 \%$ and the conductivity ranged between 462 and $11860 \mu \mathrm{S} \mathrm{cm} \mathrm{cm}^{-1}$. The salinity in the Elbe Estuary was highest during the summer months, coinciding with periods of least rainfall and low water discharge rates. The upper border of the brackish water zone was previously near Glückstadt at river km 675 (Caspers 1959). From recent investigations, it is obvious that the brackish water border has moved 5 to $20 \mathrm{~km}$ upstream (Bergemann 1995, Riedel-Lorjé et al. 1995). From January to December, the water temperature ranged from 1.3 to $25.4^{\circ} \mathrm{C}$. From +0.5 to $+2.0^{\circ} \mathrm{C}$ higher temperatures were encountered mainly in the upper part of the estuary at river $\mathrm{km} 590$ to 655 . The oxygen concentrations ranged between 2.5 and $13 \mathrm{mg} \mathrm{O}_{2} \mathrm{l}^{-1}$. They were nearly constant at all stations during winter, but during summer, minimal values were recorded in the freshwater part just downstream from Hamburg The lowest value was $2.5 \mathrm{mg} \mathrm{l}^{-1}$, determined in August at river $\mathrm{km}$ 625. From January through December, the chlorophyll a (chl a) concentration ranged from 1.0 to $184.7 \mu \mathrm{g} \mathrm{l}^{-1}$. Chl a concentrations reached maxima as

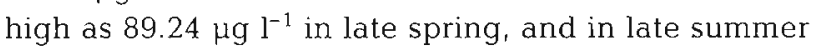
they reached $184.70 \mu \mathrm{g} \mathrm{l}^{-1}$. In the middle of March, large diatoms became dominant in the phytoplankton, and another peak was reached in August due to the presence of cyanobacteria. The highest chl a concentrations, about 5 times greater than in the brackish part, were detected in the freshwater part of the estuary (Zimmermann unpubl, data).

SPM (Fig. 2) varied between 8.0 and $654.5 \mathrm{mg} \mathrm{l}^{-1}$. Variations along the transect were low. Greatest values were reached at the freshwater-saltwater interface (Marcus Hoberg unpubl. data). In the Elbe Estuary, the number of aggregates (Fig. 3) varied between 20 and $4000 \mathrm{l}^{-1}$. The highest values, $>100$ aggregates $\mathrm{l}^{-1}$, were encountered in the part farthest downstream, from river $\mathrm{km} 675$ to 707 in the estuary. Seasonal peaks were observed during spring, in March and April, and another peak was reached in late summer and autumn, from July to October. Most aggregates were in the size range from 50 to $2500 \mu \mathrm{m}$ (Fig. 4), but several reached $5000 \mu \mathrm{m}$. In contrast to abundance, the largest size classes were found in the upstream part of the estuary, mainly in the freshwater environment.

In the Elbe Estuary, the total bacterial concentration fluctuated remarkably, with low values occurring during winter. The dynamics in abundance of free (Fig. 5) and attached organisms (Fig. 6) showed the same trend, but the variations in unattached bacteria were not as pronounced. The abundance of unattached bacteria varied between $0.5 \times 10^{9}$ and $25.5 \times 10^{9} \mathrm{l}^{-1}$, while the density of attached bacteria varied from $0.3 \times 10^{6}$ to $2.5 \times 10^{6}$ per aggregate and accounted for about $75 \%$ of the total bacterial density during the year. The mean number of bacteria estimated to be attached to a single particle in the upper estuary was $11.5 \times 10^{6}$, and at a seaward site in the estuary, the corresponding number was $0.85 \times 10^{6}$. This indicates that about $90 \%$ of the total bacterioplankton in the upper estuary were tightly attached to aggregates, while only $40 \%$ were similarly attached in the lower estuary.

The abundance of protozoans was found to be in the range from $0.242 \times 10^{6}$ to $8.78 \times 10^{6} \mathrm{l}^{-1}$. Highest values were encountered in the freshwater part of the Elbe Estuary. 


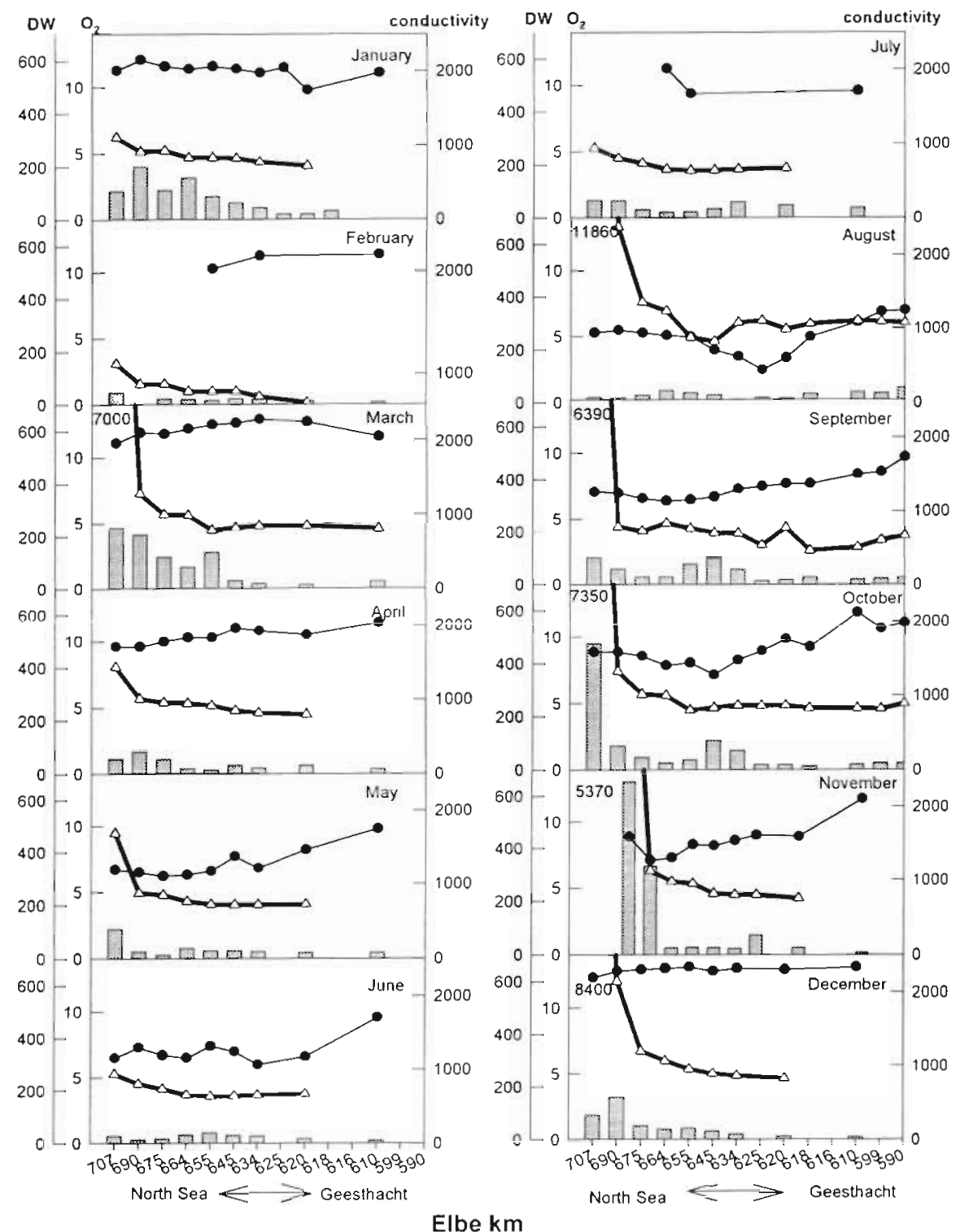

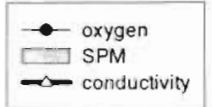

$\rightarrow$ conductivity
Fig. 2. Seasonal changes in suspended particulate matter (SPM, mg $\left.\mathrm{1}^{-1}\right)$, oxygen concentration $\left(\mathrm{O}_{2}, \mathrm{mg} \mathrm{l}^{-1}\right)$ and conductivity $\left(\mu \mathrm{S} \mathrm{cm}^{-1}\right)$ in the Elbe Estuary; DW: dry weight of SPM
Regardless of salinity, substantial populations of naked amoebae were found at all sites throughout the year. The data show a clear seasonal trend, with the highest numbers being recorded in June and July. Most amoebae were probably attached to suspended aggregates.

Ciliate abundance ranged trom $i \times i \bar{u}^{2}$ to $\bar{b} \times \bar{i} \bar{u}^{2}$ cells $1^{-1}$

The seasonal patterns of flagellate abundance varied quite markedly between $241 \times 10^{6}$ and $8748 \times 10^{6} \mathrm{l}^{-1}$. The total number of combined heterotrophic and phototrophic flagellates fluctuated throughout the year. A large proportion, about 80 to $98 \%$, of the flagellates were associated with aggregates.

Particles colonized by bacteria and protozoans were predominantly flocculent, consisting of a polysaccha- ride matrix, which is stained by Alcian Blue. The percentage of colonized particles varied between 74.5 and $98.9 \%$, with highest values recorded during summer in the upper estuary. On average, $87 \%$ of the aggregates were colonized. The mean surface area of colonized particles varied between $0.80 \mu^{2}$ and $25000.00 \mu \mathrm{m}^{2}$. The number of ailached uryanisus per unit of particle area decreased significantly with increasing particle size

\section{DISCUSSION}

The combination of high water discharge and high suspended matter concentrations in rivers is responsible for the transfer of SPM from the terrestrial environ- 
ment to the ocean (Degens \& Ittekot 1985, Ittekot 1988, Findlay et al. 1991). However, a significant fraction of the particulate organic matter entering the Elbe Estuary in Germany is metabolized or altered before it is carried into the ocean. Estuarine turbidity maxima, which result from hydrosedimentary processes, are quite characteristic among the particle-trapping mechanisms of tidal estuaries that lengthen the residence time of riverborne organic material, thereby increasing that material's availability to estuarine bacteria and the estuarine food web.

Bacteria play an important role in the trophic dynamics of aquatic food webs and in the remineralization of dissolved and particulate organic matter (Kirchman \& Mitchell 1982). The relative importance of the bacteria in the open water and those attached to particles for these processes has been determined in several aquatic environments (Ducklow 1982, Hoppe 1984, Kondratieff \& Simmons 1985). From these studies, it is known that only a small area of any given particle is colonized by bacteria (Hoppe 1984) and that the percentage of bacteria in the total community attached to particles is usually $<10 \%$ (Kirchman \& Mitchell 1982 ) but can vary from a few percent to $98 \%$ in different aquatic regions (Iriberri et al. 1987, Berger et al. 1996, Zimmermann \& Kausch 1996). The large variations in the percentage of bacteria attached to different kinds of aggregates can be attributed to different abiotic and biotic conditions that were evident during different seasons and at different locations in the Elbe Estuary (Zimmermann unpubl. data).

Aggregates in the Elbe Estuary showed seasonal differences in size, morphology and content. During spring, aggregates harboured intact diatoms, loricas of tintinnids and faecal pellets of copepods (Zimmermann \& Kausch 1996). During summer, large amounts of detritus and cyanobacteria were in the particles, and in autumn, they contained material from macrophytes. During winter, many mineral particles were present (Zimmermann et al. in press). The correlation (Table 1) between aggregate abundance and the number of attached bacteria suggests that not all aggregates sup- port colonization by bacteria. The particles can vary in 2 important ways: their total organic content and their size. Zimmermann et al. (in press) showed that the total organic content of particles varies considerably. For example, during winter when the water discharge rate is high, mineral particles are very abundant. Aggregates in the lower part of the estuary have an organic matter content of only about 10 to $30 \%$. Probably due to the greater resuspension of sand grains and other inorganic particles, the number of attached bacteria on those aggregates remains low: $0.3 \times 10^{6}$ to $6 \times 10^{6}$ bacteria per aggregate. The greater abundances of bacteria found at the upstream estuarine sites and the variations in abundance throughout 


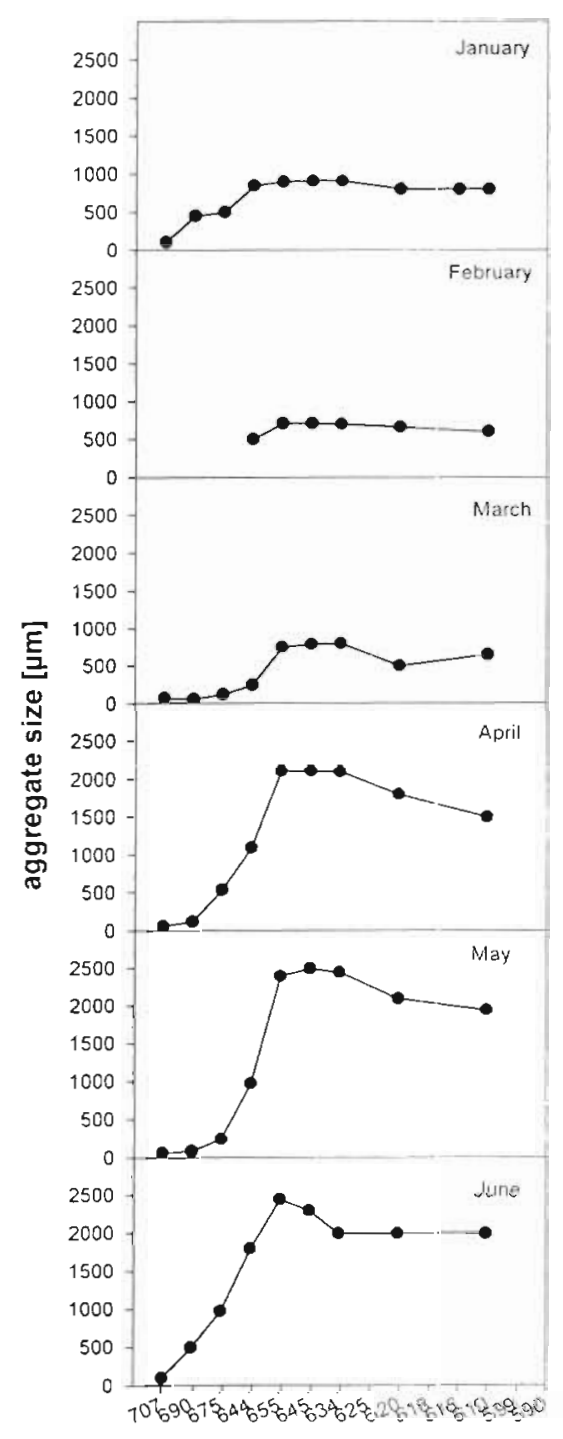

North Sea $\rightleftharpoons$ Gresthacht

\section{Elbe km}

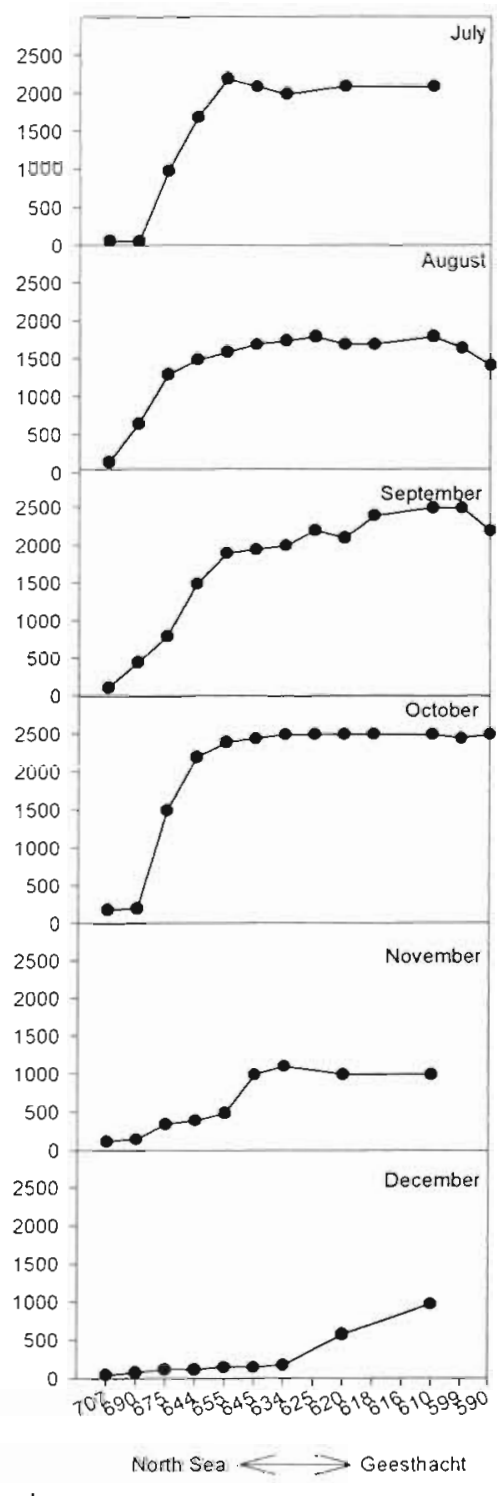

North Sea $<$ Geesthacht the year can be attributed, in part, to the great size of the aggregates in the water column. They are composed of a large amount of fresh material from algae or macrophytes. Both floristic elements are produced in the Elbe above Hamburg or in shallow and slow-flowing tributaries (Wolfstein \& Kies 1995, Marcus Hoberg pers. comm., Zimmermann unpubl. data). The composition of the particulate organic material also changes as it is consumed by bacteria and other grazers, becoming less labile and supporting a less productive complement of bacteria (Crump \& Baross 1996, Jürgens et al. 1997). Some turbid regions in some estuaries may support greater bacterial abundance than waters with low turbidity (Bent \& Goulder 1981, Joint \& Pomeroy 1982, Plummer et al. 1987, Painchaud \& Therriault 1989). Downstream, SPM concentrations increasing to values 2 to 15 times greater than that in the upper part of the estuary is characteristic of the lower Elbe. The hydrological processes cause a nearly permanent suspension of material from the freshwater and the marine region. There are large numbers of bacteria in this region, where aggregates are small only when their organic content is

Fig. 4. Seasonal changes in aggregate size in the Elbe Estuary

Table 1. Spearman's correlation matrix of Elbe Estuary $(n=85)$ parameters. The correlation coefficient (r) was computed among the following parameters: abundance of attached bacteria (bacteria aggregate ${ }^{-1}$ ), abundance of free bacteria (bacteria $\mathrm{l}^{-1}$ ), abundance of aggregates (aggregates $\left.\mathrm{l}^{-1}\right)$, aggregates size $(\mu \mathrm{m})$, chlorophyll a $\left(\mu \mathrm{g} \mathrm{l^{-1 }}\right)$, temperature $\left({ }^{\circ} \mathrm{C}\right)$, conductivity $(\mu \mathrm{S} \mathrm{cm})$, abundance of ciliates (cells $\mathrm{l}^{-1}$ ), flagellates $\left(\right.$ cells ${ }^{-1}$ ) and discharge $\left(\mathrm{m}^{3} \mathrm{~s}^{-1}\right)$. Significance level: ${ }^{*} 5.0 \%, \cdots 1.0 \%, \cdots 0.1 \%$

\begin{tabular}{|c|c|c|c|c|c|c|c|c|c|c|}
\hline & $\begin{array}{c}\text { Attached } \\
\text { bacteria }\end{array}$ & $\begin{array}{c}\text { Aggregate } \\
\text { size }\end{array}$ & $\begin{array}{c}\text { Free } \\
\text { bacteria }\end{array}$ & Aggregate & Chl a & $\begin{array}{l}\text { Temper- } \\
\text { ature }\end{array}$ & $\begin{array}{l}\text { Conduc- } \\
\text { tivity }\end{array}$ & Ciliates & $\begin{array}{c}\text { Flagel- } \\
\text { lates }\end{array}$ & Discharge \\
\hline Attached bacteria & a 1 & - & - & - & - & - & - & - & - & - \\
\hline Aggregate size & $0.675^{\cdots}$ & 1 & - & - & - & - & - & - & - & - \\
\hline Free bacteria & $0.848 \cdots$ & $0.652 \cdots$ & 1 & -- & - & - & - & - & - & - \\
\hline Aggregate & -0.118 & $-0.305 \cdots$ & -0.049 & 1 & - & - & - & - & - & - \\
\hline Chl a & $0.667 \cdots$ & $0.405 \cdots$ & $0.717 \cdots$ & -0.124 & 1 & - & - & - & - & - \\
\hline Temperature & $0.477^{\circ}$ & $0.497 \cdots$ & $0.690^{\cdots}$ & $-0.205^{\circ}$ & $0.500 \cdots$ & 1 & - & - & - & - \\
\hline Conductivity & $-0.245 \cdots$ & $-0.361 \cdots$ & $-0.147^{\circ}$ & 0.254 & $-0.185 \cdots$ & 0.019 & 1 & - & - & - \\
\hline Ciliates & $0.366 \cdots$ & $0.493 \cdots$ & $0.488 \cdots$ & $-0.404 \cdots$ & $0.364^{\circ}$ & $0.411^{\circ}$ & $-0.588 \cdots$ & 1 & - & - \\
\hline Flagellates & $0.540 \cdots$ & $0.493 \cdots$ & $0.620^{\cdots}$ & $-0.397 \cdots$ & $0.508 \cdots$ & 0.338 & -0.291 & $0.663 \cdots$ & 1. & - \\
\hline Discharge & $-0.303 \cdots$ & $-0.186 \cdots$ & $-0.436 \cdots$ & -0.128 & -0.117 & $-0.274 \cdots$ & -0.222 & $0.280^{\cdots}$ & $0.055 \cdots$ & 1 \\
\hline
\end{tabular}


high. Most of the material from the freshwater zone decomposed on its way downstream.

The significant correlation between the abundance of attached bacteria and the size of the aggregates (Table 1) is positive. In most cases, large particles typically occur when the organic content is great (Zimmermann \& Kausch 1996, Zimmermann unpubl.). It was reported by Hoppe (1984) that the characteristics of the particles and their adsorption capacities determine the degree of colonization. Many particles and interfaces may not provide the conditions necessary for the successful competition of attached bacteria with bacteria in the water. Most of the attached bacteria colonizing the aggregates in their late stages are not affected by the spatial and temporal changes, are larger in size (Zimmermann \& Kausch 1996) and are more active than those dispersed in the pelagic water column (Hodson et al. 1981, Iriberri et al. 1987, Unanue et al. 1992, Griffith et al. 1994). Spatial variations in their concentration were correlated in part with changes in the amounts of aggregates.

The conclusion that bacteria attached to particles account for increases in estuarine turbidity (Table 1) is contrary to the observation that smaller aggregates were more abundant outside the zone of maximum turbidity in the estuary (Crump \& Baross 1996). The numbers of bacteria were greatest on flocculent, 'permanently suspended particles', particles that had not settled out after $6 \mathrm{~h}$ in a settling chamber (Zimmermann unpubl. data).

The number of bacteria did not correlate significantly with salinity (Table 1 ). It seems that colonization of aggregates by bacteria occurs independently of changes in salinity in the estuary. Nevertheless, there are direct effects from temperature (Table 1) and indirect effects related to light and temperature (Table 1). Temperature has been regarded as crucial for the oxygen regime in the Elbe Estuary because microbial processes depend greatly on temperature (Rheinheimer 1964, Flügge 1985). Aggregates which differed significantly in their organic composition were markedly affected by microbial degradation processes at water temperatures above $15^{\circ} \mathrm{C}$. Generally, first indications of increasing oxygen deficiencies become detectable during late spring, in May, at the lower end of the freshwater region. With increasing temperature, the area of oxygen minima moves upstream and might produce critical conditions for the fish (Kerner et al. 1995) in August. The data reveal that during the cold season, from December to April, the oxygen concentrations remained constant along the whole transect and that an increased abundance of aggregates was not accompanied by a corresponding decrease in the oxygen concentration (Figs. 2 \& 3). Bright illumination and high temperature provoke a spring proliferation of algae, especially diatoms, and the sticky diatoms are an important component of the first large aggregates that form during spring (Zimmermann \& Kausch 1996). 


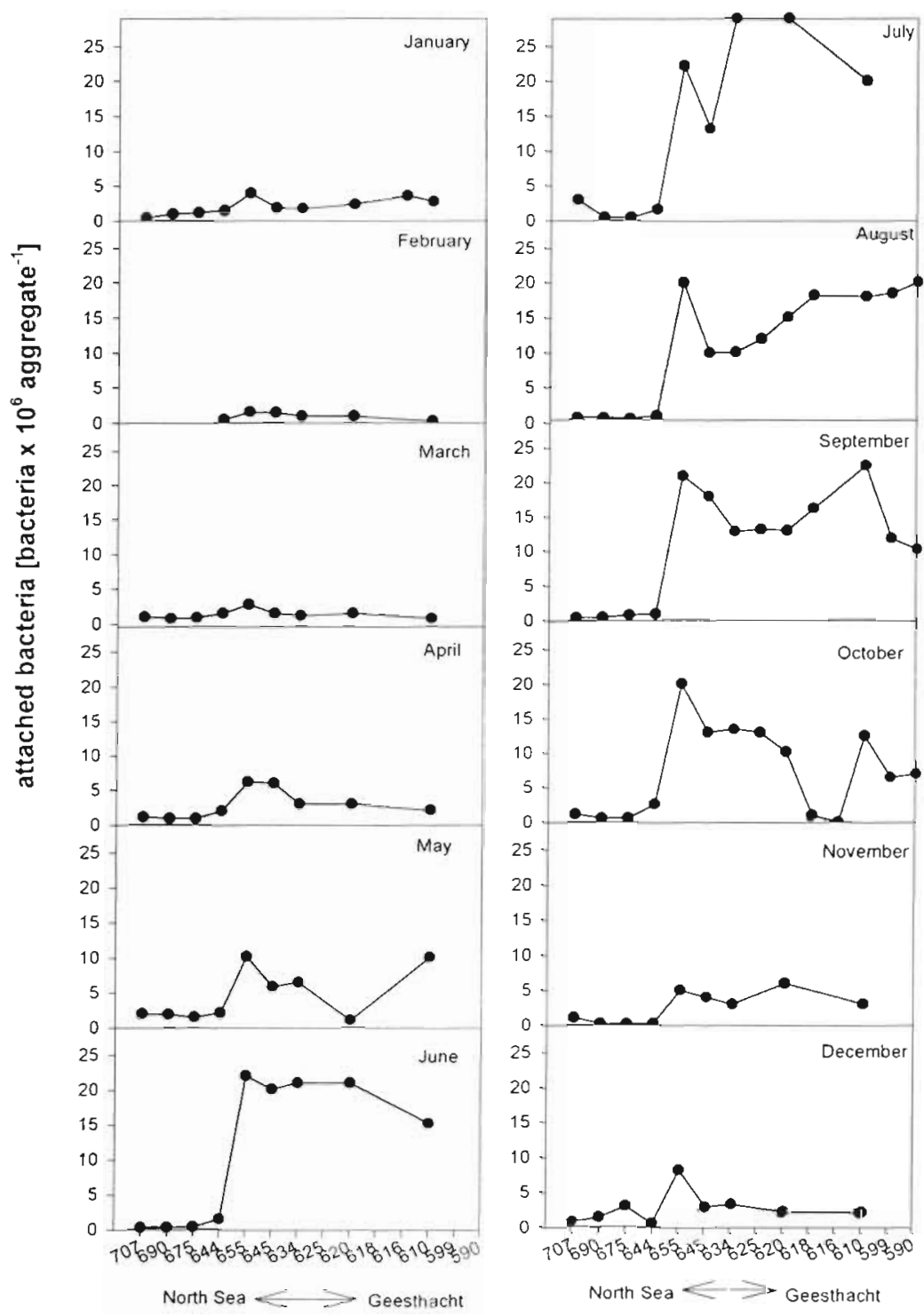

Elbe $\mathrm{km}$

Fig. 6. Bacterial abundance on aggregates in the Elbe Estuary

ond algal maximum utilizing a large part of algal detritus. During periods of minimal oxygen concentrations, the chl a content is very low. In addition, reduced illumination in the lower part of the turbid estuary minimizes algal capacity to produce oxygen by photosynthesis.

There is a diverse fauna of pelagic and epibenthic bacterivores in the estuary. The dominant species include amoebae, ciliates, flagellates, larvae of Dreissena polymorpha, nematodes and rotifers. Due to the abundance of bacteria attached to particles, bacterial carbon in the estuary is parkaged in particles of many sizes and may be available as food to all of these grazers. Bacteria may be consumed at many different trophic levels within the plankton, complicating and 'short-circuiting' the microbial food web (Lampitt et al. 1993, Zimmermann et al. in press).

Correlations between the abundance of the dominant grazers and the different bacterial parameters provided some clues to the structure of the detrital food web at different locations in the Elbe Estuary. Protozoans are capable of rapid growth in response to an increase in their food supply, so it was not unexpected to find a significant positive correlation between the abundances of flagellates and bacteria and those of ciliates and bacteria (Table 1). At individual locations in the Elbe Estuary, a balance between bacterial growth and grazing might have been the reason for the temporary uniformity of the total number of bacterial cells observed during this study. Many organisms are able

From chlorophyll determinations, it was deduced that a large portion of algae are lost downstream in the estuary and transformed to algal detritus. It is known from the investigation by Fast (1993) that the chl a content of the Elbe water decreases drastically downstream from Hamburg long before the salinity gradient is reached. Algae attached to aggregates have a higher sinking velocity than algae suspended freely in the water and are subject to sedimentation and resuspension processes (Wolfstein \& Kies 1995). It seems that oxygen demand in August downstream from Hamburg (Fig. 2) is increased by the activity of heterotrophic bacteria (Böttcher et al. 1995, Wolfstein \& Kies 1995) which degrade organic material produced by the sec- to graze on dispersed or loosely attached bacteria (Laybourn-Parry et al. 1987, Rogerson et al. 1989, PolneFuller et al. 1990, Rogerson 1991, Arndt 1993, Jürgens \& Güde 1994), and others consume whole aggregates (Heinle \& Flemer 1975, Heinle et al. 1977, Chervin 1978, Boak \& Golder 1983, Zimmermann et al. in press, Zimmermann \& Barkmann unpubl.). However, no correlation was found for the number of aggregates; only the size of the aggregates is an important factor.

At least 2 factors control the level of bacterial abundance in the water column of the Elbe Estuary. In the upstream part of the estuary, bacterial abundance is under strong grazing control, whereas in the seaward part, substrate limitation reduces bacterial growth. 
Acknowledgements. I thank my colleagues for all their help in the field, in particular M. Hoberg, H. Holst, S. Müller and A. Tondern and the team of the RV 'Tromper Wiek' with H. Neumann and J. Lingner. Thanks are also due to C. W. Heckman, who corrected the English. I also gratefully acknowledge the support of T. Gaumert and M. Hoberg, who provided data on water discharge rates and SPM, and $H$. Weikert for the use of the epifluorescence microscope. This work was supported by the Deutsche Forschungsgemeinschaft Sonderforschungsbereich-327 and the 'Aktion seeklar' in Hamburg. Thanks are also due to $H$. Kausch and 3 anonymous reviewers for constructive criticism of an earlier version of this manuscript.

\section{LITERATURE CITED}

Anderson P. Sørenson HM (1986) Population dynamics and trophic coupling in pelagic microorganisms in eutrophic coastal waters. Mar Ecol Prog Ser 33:99-109

Arndt $H$ (1993) A critical review of the importance of rhizopods (naked and testate amoebae) and actinopods (heliozoa) in lake plankton. Mar Microb Food Webs 7:3-29

Azam F, Fenchel T, Field JG, Gray JS, Meyer-Reil LA, Thingstad F (1983) The ecological role of water-column microbes in the sea. Mar Ecol Prog Ser 10:257-263

Bent EJ, Goulder R (1981) Planktonic bacteria in the Humber Estuary; seasonal variation in population density and heterotrophic activity. Mar Biol 62:35-45

Bergemann M (1995) Die Lage der oberen Brackwassergrenze im Elbeästuar. Dt Gewässerkundl Mitt 39(4/5): $134-137$

Berger B, Hoch BM, Kavka G, Herndl GJ (1996) Bacterial colonization of suspended solids in the River Danube. Aquat Microb Ecol 10:37-44

Boak AC, Goulder R (1983) Bacterioplankton in the diet of the calanoid copepod Eurytemora sp. in the Humber estuary. Mar Biol 73:139-149

Böttcher B, Dittberner P, Rath G, Schäfer B, Zörner S, Koops HP (1995) A case study on the oxgen budget in the freshwater part of the Elbe estuary. 4. Bacterial population shifts and rising oxygen deficiencies. Arch Hydrobiol/ Suppl 110, Unters Elbe-Aestuar 7:55-76

Burkill PH (1982) Ciliates and other microplankton components of a nearshore foodweb. Standing stock and production processes. Ann Inst Oceanogr, Paris 58:335-350

Capriulo GM, Carpenter EJ (1983) Abundance, species composition and feeding impact of tintinnid micro-zooplankton in central Long Island Sound. Mar Ecol Prog Ser 10: $277-288$

Capriulo GM, Ninivaggi DV (1982) A comparison of feeding activities of field collected copepods fed identical natural particle assemblages. Ann Inst Oceanogr, Paris 59: 325-334

Caron DA, Davis PG, Madin LP, Sieburth JMcN (1982) Heterotrophic bacteria and bacterivorous protozoa in oceanic macroaggregates. Science 218:795-797

Caspers H (1959) Die Einteilung der Brackwasser-Regionen in einem Ästuar. Arch Oceanogr Limnol (Suppl) 11:155-169

Chervin MB (1978) Assimilation of particulate organic carbon by estuarine and coastal copepods. Mar Biol 49:265-278

Crump BC, Baross JA (1996) Particle-attached bacteria and heterotrophic plankton associated with the Columbia River estuarine turbidity maxima. Mar Ecol Prog Ser 138: $265-273$

Decho AW (1990) Microbial exopolymer secretions in ocean environments: their role(s) in food webs and marine processes. Oceanogr Mar Biol 28:73-153
Degens ET, Ittekot V (1985) Particulate organic carbon: an overview. Mitt Geol-Paläontol Inst Univ Hamburg SCOPE-UNEP Sonderbd 58:7-27

Ducklow HW (1982) Chesapeake Bay nutrient and plankton dynamics. 1. Bacterial biomass during spring tidal destratification in the York River, Virginia estuary. Limnol Oceanogr 27:651-659

Eisma D (1992) Suspended. matter in the aquatic environment. Springer-Verlag, Berlin

Fast T (1993) Zur Dynamik von Biomasse und Primärproduktion des Phytoplanktons im Elbe-Ästuar. PhD thesis, Univ Hamburg

Fenchel T (1982) Ecology of heterotrophic microflagellates. IV. Quantitative importance and importance as bacterial consumers. Mar Ecol Prog Ser 9:35-42

Findlay S, Pace M, Lints D (1991) Variability and transport of suspended sediment, particulate and dissolved organic carbon in the tidal freshwater Hudson River. Biogeochemistry 12:149-169

Flügge G (1985) Gewässerökologische Überwachung der Elbe-Sauerstoffmangel/Fischsterben/Schwermetall/chlorierte Kohlenwasserstoffe-Analyse der Ursachen. Abh Naturw Verein Bremen 40:217-232

Goulder R (1976) Relationships between suspended solids and standing crop and activities of bacteria in an estuary during a neap-spring tidal cycle. Oecologia 24:83-90

Goulder R (1977) Attached and free bacteria in an estuary with abundant suspended solids. J Appl Bacteriol 43:399-405

Greiser N (1988) Zur Dynamik von Schwebstoffen und ihren biologischen Komponenten in der Elbe bei Hamburg. PhD thesis, Univ Hamburg

Griffith P, Shiah FK, Gloersen K, Ducklow HW, Fletcher M (1994) Activity and distribution of attached bacteria in Chesapeake Bay. Mar Ecol Prog Ser 108:1-10

Grossart HP, Simon M (1993) Limnetic macroscopic organic aggregates (lake snow): occurrence, characteristics, and microbial dynamics in Lake Constance. Limnol Oceanogr $38(3): 532-546$

Hansen PJ (1991) Quantitative importance and trophic role of heterotrophic dinoflagellates in coastal pelagic food webs Mar Ecol Prog Ser 73:253-261

Hargreaves PE (1981) Seasonal variation of tintinnids (Ciliopora, Oligotrichida) in Narragansett Bay, Rhode Island, U.S.A. J Plankton Res 3:81-91

Hedin $\mathrm{H}$ (1975) On the ecology of tintinnids on the Swedish west coast. Zoon 3:125-140

Heinle DR, Flemer DA (1975) Carbon requirements of a population of the estuarine copepod Eurytemora affinis. Mar Biol 31:235-247

Heinle DR, Harris RP, Ustach JF, Flemer DA (1977) Detritus as food for estuarine copepods. Mar Biol 40:341-353

Henrot L (1983) Marine pelagic rotifers and tintinnidsimportant trophic links in the spring plankton community of the Gullmar Fjord, Sweden. J Plankton Res 5:835-846

Hodson RE, Maccubbin AE, Pomeroy LR (1981) Dissolved adenosine triphosphate utilization by free-living and attached bacterioplankton. Mar Biol 64:43-51

Holst H (1996) Untersuchungen zur Ökologie der Rotatorien auf den Schwebstoffflocken und im Freiwasser der Elbe während des Frühjahrs. $M$ thesis, Univ Göttingen

Hoppe HG (1984) Attachment of bacteria: advantage or disadvantage for survival in the aquatic environment. In: Marshall KC (ed) Microbial adhesion and aggregation. Springer, Berlin, p 283-301

Humann K (1996) Der Einfluß des Mikrophytobenthos auf die Sedimentstabilität und die Schwebstoffbildung aus Sedimenten in Elbe-Ästuar. PhD thesis, Univ Hamburg 
Iriberri J, Unanue M, Barcina I, Egia L (1987) SeasonaI variation in population density and heterotrophic activity of attached and free-living bacteria in coastal waters. Appl Environ Microbiol 53:2308-2314

Ittekot V (1988) Global trends in the nature of organic matter in river suspensions. Nature 332:436-4.38

Joint IR, Pomeroy AJ (1982) Aspects of microbial heterotrophic production in a highly turbid estuary. J Exp Mar Biol Ecol 58:33-46

Jurgens $K_{1}$ Arndt $H$, Zimmermann $H$ (1997) Impact of metazoan and protozoan grazers on bacterial biomass distribution in microcosm experiments. Aquat Microb Ecol 12: $131-138$

Jürgens K, Güde H (1994) The potential importance of grazing-resistant bacteria in planktonic systems. Mar Ecol Prog Ser 112:169-188

Kerner M, Kappenberg J, Brockmann U, Edelkraut F (1995) A case study on the oxygen budget in the freshwater part of the Elbe estuary. 1. The effect of changes in physicochemical conditions on the oxygen consumption. Arch Hydrobiol/Suppl 110, Unters Elbe-Aestuar 7:1-25

Kies L (1995) Algal snow and the contribution of algae to suspended particulate matter in the Elbe estuary. In: Wiessner W, Schnepf E, Starr RC (eds) Algae, environment and human affairs. Biopress Limited, Bristol, p 93-121

Kirchman D, Mitchell R (1982) Contribution of particle-bound bacteria to total microheterotrophic activity in five ponds and two marshes. Appl Environ Microbiol 43:200-209

Kondratieff PF, Simmons GM (1985) Microbial colonization of seston and free bacteria in an impounded river. Hydrobiologia 128:127-133

Lampitt RS, Wishner KF, Turley CM, Vogel MV (1993) Marine snow studies in the Northeast Atlantic Ocean: distribution, composition and role as a food source for migrating plankton. Mar Biol 116:689-702

Laybourn-Parry J, Jones K, Holdich JP (1987) Grazing by Mayorella sp. (Protozoa: Sarcodina) on cyanobacteria. Funct Ecol 1:99-104

Laybourn-Parry J, Rogerson A, Crawford DW (1992) Temporal patterns of protozooplankton abundance in the Clyde and Loch Striven. Estuar Coast Shelf Sci 35:533-545

Mc Cluskey DS (1989) The estuarine ecosystem. Blackie, Glasgow

Nusch EA (1980) Comparison of different methods for chlorophyll and phaeopigment determination. Arch Hydrobiol, Beih Ergebn Limnol 14:14-36

Painchaud J, Therriault JC (1989) Relationships between bacteria, phytoplankton and particulate organic carbon in the Upper St. Lawrence Estuary. Mar Ecol Prog Ser 56: 301-311

Plummer DH, Owens NJP, Herbert EA (1987) Bacteria-particle interactions in turbid estuarine environments. Cont Shelf Res 7(11/12):1429-1433

Polne-Fuller M, Rogerson A, Amano H, Gibor A (1990) Digestion of seaweeds by the marine amoeba Trichosphaerium. Hydrobiologia 204/5:409-41.3

Responsible Subject Editor: T. F. Thingstad, Roskilde, Denmark
Pomeroy LR (1974) The ocean's food web, a changing paradigm. BioSci 24:499-504

Rheinheimer G (1964) Untersuchungen über den Einfluß der Temperatur auf die Nitrifikation im Elbe-Aestuar. Arch Microbiol 49:283-290

Riedel-Lorjé JC, Kohla U, Vaessen B (1995) Das Vordringen ausgewählter Bodentiere im Elbe Ästuar als Indikator für eine Verlagerung der oberen Brackwassergrenze. Dt Gewässerkdl Mitt 39H(4/5):137-145

Rogerson A (1991) On the abundance of marine naked amoebae on the surfaces of five species of macroalgae. FEMS Microbiol Ecol 85:301-312

Rogerson A, Laybourn-Parry J (1992a) Aggregate dwelling protozooplankton communities in estuaries. Arch Hydrobiol 125(4):411-422

Rogerson A, Laybourn-Parry $J(1992 b)$ The abundance of marine naked amoebae in the water column of the Clyde Estuary. Estuar Coast Shelf Sci 34:187-196

Rogerson A, Polne-Fuller M. Trench RK, Gibor A (1989) A laboratory-induced association between the marine amoeba Trichosphaerium AM-I-7 and the dinoflagellate Symbiodinium. Symbiosis 7:229-241

Sanders RW (1987) Tintinnids and other microzooplanlxton, seasonal distribution and relationships to resources and hydrography in a Maine estuary. J Plankton Res 9:65-77

Sime-Ngando T, Gosselin M, Roy S, Chanut JP (1995) Significance of planktonic ciliated protozoa in the Lower. St. Lawrence Estuary: comparison with bacterial, phytoplankton, and particulate organic carbon. Aquat Microb Ecol 9:243-258

Smetacek V (1981) The annual cycle of protozooplankton in the Kiel Bight. Mar Biol 63:1-11

Unanue M, Ayo B, Azúa I, Barcina I, Iriberri J (1992) Temporal varibility of attached and free-living bacteria in coastal waters. Microb Ecol 23:27-39

Williams PJLeB (1981) Incorporation of microheterotrophic processes into the classical paradigm of the plankton food web. Kieler Meeresforsch Sonderh 5:1-28

Wolfstein K (1996) Untersuchungen zur Bedeutung des Phytoplanktons als Bestandteil der Schwebstoffe für das Ökosystem Tide-Elbe. PhD thesis, Univ Hamburg

Wolfstein K, Kies L (1995) A case study on the oxygen budget in the freshwater part of the Elbe estuary. 3. Variations in phytoplankton pigments in the Elbe estuary before and during the oxygen minima in 1992 and 1993. Arch Hydrobiol/Suppl 110, Unters Elbe-Aestuar 7:39-54

Zimmermann $\mathrm{H}$, Holst $\mathrm{H}$, Müller S (in press) Seasonal dynamics of aggregates and their typical biocoenosis in the Elbe Estuary. Estuaries

Zimmermann $H$, Kausch $H$ (1996) Microaggregates in the Elbe Estuary: structure and colonization during spring. Arch Hydrobiol, Spec Issues Advanc Limnol 48:85-92

Zimmermann R (1975) Entwicklung and Anwendung von fluoreszenz- und rasterelektronenmikroskopischen Methoden zur Entwicklung in Wasserproben. PhD thesis, Univ Kiel

Manuscript received: January 10,1997

Revised version accepted: February 10, 1997 